\title{
Çevirmek İçin Çözümlemek: Bel Kaufman'un Sunday in the Park Başlıklı Öyküsünde Anlam Arayışı
}

\section{Didem TUNA ${ }^{1}$}

\begin{abstract}
Özet
Yazınsal bir metnin varış diline anlam evrenini oluşturan göstergeleri ile birlikte aktarılmasında, metin üzerinde uygulanacak göstergebilimsel çözümlemenin önemli bir katkısından söz edilebilir. Çevirmenin yapacağı çözümleme metni göstergeleriyle birlikte okumasını ve bu sayede de varış metnine göstergeleriyle aktarmasını sağlar. Öte yandan, söz konusu olan kısa bir öykü ise, göstergebilimsel çözümleme çeviriye ayrı bir katkı sunabilir, zira kısa öyküde anlam evrenini olușturan ve sonuca bağlayan göstergelerin sayısı sınırlıdır. Az sözcükle çok şey ifade edilir ve bu nedenle de göstergelerin atlanmaması kısa öyküde özel önem taşır. Bu çalışma kapsamında, Amerikalı yazar Bel Kaufman'ın daha önce Türkçeye çevrilmemiş olan Sunday in the Park adlı kısa öyküsü, Paris Göstergebilim Okulunda geliştirilen bazı çözümleme yöntemleri ile ele alınmıştır. Metin öncelikle kesitlenecek ve gerçeğe uygunluk durumları (olmak/görünmek) değerlendirilecek, bunun yanı sıra metindeki yerdeşlikler, sözleşmeler ve eyleyenlerin kipsel donanımları ele alınmıştır. Sonrasında, bu yöntemlerle okunan ve öykü için özel önemi bulunan kimi göstergelerin Türkçeye nasıl aktarılabileceği ve her bir farklı aktarımın anlam üzerinde yaratacağı farklı etkiler tartışılmış ve göstergebilimin çeviriye sunabileceği katkıdan söz edilmiştir.
\end{abstract}

Anahtar sözcükler: Çeviri Göstergebilimi, Paris Göstergebilim Okulu, Bel Kaufman, Sunday in the Park.

\section{Analyzing to Translate: Quest for Meaning in Bel Kaufman's Sunday in the Park}

\begin{abstract}
In the translation of a literary text with the signs that constitue its universe of meaning into a target language, a semiotic analysis applied to the text may have a significant contribution to make. The analysis made by the translator may help her/him to read and convert the text to the target language, together with its signs. Furthermore, when a short story is in question, semiotic analysis may be particularly useful because, in a short story, the number of signs that constitue the universe of meaning and that lead to the conclusion is limited. Many things are meant in a few words, and this is why it is important not to leave out any of the signs. In this study, Sunday in the Park, a short story by an American author, Bell Kaufman, which was not previously translated into Turkish will be treated with some of the methods of analysis developped by the Paris School of Semiotics. First, the text will be segmented and veridictory modalities (seeming/being) will be evaluated. Then, isotopies and contracts in the text and combinatory modalities of the actants will be studied. Finally, how the signs that are read with these methods and that have a specific importance for the story can be transmitted into Turkish will be discussed, specifying how different translations can have different influences on meaning and in what ways semiotics could contribute to translation.
\end{abstract}

Keywords: Semiotics of Translation, Paris School of Semiotics, Bel Kaufman, Sunday in the Park.

Dr., Galatasaray Üniversitesi, Galatasaray Lisesi, berk4005@hotmail.com

Adres e-posta: editor@rumelide.com 


\section{Giriş}

"Kısa öykü, kısa bir öyküdür. Bu da, önemli bir cümledir. Kısalığı nedeniyle, çokça karakteri, ikinci derecede olayları ya da arasözü olamaz [...] Her cümle sonuca, hem şaşırtıcı, hem de kaçınılmaz görünmesi gereken bir açığa çıkma ya da kavrayış anına işaret etmelidir" (Kaufman, 2012, 7). Bu çalışmamıza konu olan Sunday in the Park adll kısa öykünün Amerikalı yazarı Bel Kaufman’ın tanımına baktığımızda, bu türdeki her bir göstergenin özel önem taşıyabileceğini görüyoruz; çünkü öykünün kısa olması nedeniyle, anlam evrenini satırlarda ve satır aralarında dokuyarak sonuca bağlayan göstergeler de doğal olarak sayıca sınırlı olmak durumundadır. Az göstergeyle çok şey ifade edildiğinde oluşan anlamların tek tek yakalanması ise dikkatli bir okuma gerektirecektir. Bu noktada, yazınsal metne yönelik geliştirilen gösterge okuma ve çözümleme yöntemlerinden yararlanılabilir. Bu çalışmada, bu amaca yönelik olarak Paris Göstergebilim Okulu tarafından kullanılan ceșitli yöntemlerden Kaufman'ın Sunday in the Park adlı kısa öyküsü için uygun olduğu düşünülen kesitleme, gerçeğe uygunluk durumlarının (olmak/görünmek) değerlendirilmesi, yerdeşlikler, sözleşmeler ve eyleyenlerin kipsel donanımlarının incelenmesi yöntemlerinden yararlanılacaktır. Özgün metin üzerinde bu yöntemlerin kullanılmasıly yapılacak göstergebilimsel çözümlemenin, metnin daha iyi okunmasını sağlayabileceği ve böylelikle metnin çevirisine de katkı sunacağı düşünülmektedir. ${ }^{2}$

Çözümlemeye ya da neden özellikle bu yöntemlerin seçildiğine geçmeden evvel, yapıtları dilimize henüz çevrilmemiş Bel Kaufman'ın yaşam öyküsünde sıra dışı sayılabilecek birkaç ayrıntıdan söz edelim. Kaufman, Rus anne ve babanın kızı olarak 1911 yılında babasının tıp öğrenimi gördüğü Berlin'de dünyaya gelmiştir. Ana dili Rusçadır. Çocukluğu Odessa'da geçer. Annesi ve dedesi de yazardır. Rus devrimi sırasında Moskova'da bulunmaktadır. Yahudi bir aile olarak çeşitli güçlüklerle karşılaşırlar. 1923 yılında 12 yaşındayken aile New York'a göç eder. Dil kısıtı nedeniyle başta birinci sınıfa yerleştirilir. İngilizceyi burada öğrenecek ve sonradan öğrenilmiş bu dilde yazdıklarıyla ünlenecektir. Hunter College ve ardından Columbia Üniversitesi'nde başarılı bir öğrenim süreci geçiren Kaufmann, lise öğretmenliği yapmak ister; zira Kaufman’a göre üniversite öğrencilerinin üzerinde bir etki yaratmak zordur, oysa lise öğrencileri için bir fark yaratabileceğini, onlara okuma, yazma ve öğrenme keyfini aşlayabileceğini düşünür. Hafif bir Rus aksanı ile konuşuyor olması öğretmenlik yolunda önüne engel olarak çıksa da sonrasında bu isteği gerçek olacak ve yaşamını öğretmen ve yazar olarak sürdürecektir. Esquire dergisinde yazarken Belle olan adını Bel şeklinde kısaltır; zira dergi kadın yazar kabul etmemektedir. İsim de bu şekliyle biraz anlaşılmaz kalmakta ve kadın adı olarak algılanmamaktadır. Kaufman, bundan sonra daima bu adı kullanacaktır. 1965 yllında Up the Down Staircase adlı ilk romanı yayımlanır ve 64 hafta boyunca New York Times'ın en çok satanlar listesinde yer alır. Bu başarıdan sonra öğretmenlere yönelik konferansların aranan konuşmacısı olur, hem de yine sonradan öğrenilmiş ve aksanlı İngilizcesiyle. 1979 yılında ise Love, etc. adlı ikinci romanı yayımlanır. Birçok kısa öyküsü de bulunan Kaufmann, 2014 yılında, 103 yaşında ölür. Son zamanlarına kadar yazmaya, konuşmaya ve hatta Hunter College bünyesinde kurum tarihinin en yaşlı hocası unvanı ile dersler vermeye devam eder.

İnceleyeceğimiz Sunday in the Park adlı kısa öyküde, Morton ve karısı, güneşli bir Pazar günü küçük oğulları Larry ile birlikte parka gider. Aile sıradan bir aile, gün sıradan bir gün,

$\mathrm{Bu}$ çalışmada benimsediğimiz Çeviri Göstergebilimi yaklaşımı, Paris Göstergebilim Okulu çerçevesinde oluşturulmuş gösterge kuramlarını çeviri edimine uygulanması suretiyle Sündüz Öztürk Kasar tarafından önerilmiştir. Kasar, bu yöntemi Fransız çeviribilimci Antoine Berman’dan esinlenerek oluşturduğu “Anlam Bozucu Eğilimler Dizgeselliği” ile geliştirmektedir. 
park ise sıradan bir parktır. O pazar saat beş buçukta o parkta sadece 8 kişi vardır, bunların üçü öyküde hiçbir rol oynamadan çıkıp gidecektir. Geriye Morton, karısı, oğlu Larry, diğer bir adam ve onun oğlu Joe kalır. Bu noktada, iki küçük çocuk arasında aniden ve rastlantısal olarak oluşan bir durum düşünülmeyenleri düşündürecek, söylenmeyenleri söyletecek ve Morton ile karısının sürdürdükleri birlikteliğin dengeleri büyük olasılıkla bir daha eskisi gibi olamayacaktır.

Öykünün ana sorunsalının bir şeyleri hazmedememe, kaldıramama ve gururuna yedirememe üzerine kurulu olduğu söylenebilir. Öykünün ikincil sorunsalları ise daha küçük boyutlarda da olsa yine hazmedememe, kaldıramama ve gururuna yedirememe durumlarına dayanmaktadır. İlk planda görünür olmamakla birlikte ana sorunsal aslında Morton ve karısı bağlamında yaşanmakta, ikinci sorunsal ise çocuk (Larry) ve öteki çocuk (Joe), kadın ve öteki çocuk (Joe), kadın ve öteki adam, Morton ve öteki adam, Larry ile annesi (kadın) ve babası (Morton) bağlamında kendini göstermektedir. Bu kişiler arasında öyküde geçen her tür iletişim, hem öykünün sonunun hem de öykü ötesinin belirleyicisi olarak düşünülebilir.

Paris Göstergebilim Okulu çalışmaları kapsamında yazınsal metne yönelik birçok çözümleme yöntemi geliştirilmiş ve kullanılmıştır. Ancak bu çalışma için seçtiğimiz metnin kısa öykü olması, çözümleme yöntemlerinin çeşitlendirilmesi açısından bir kısıt oluşturmaktadır. Örneğin, her ne kadar alımlayan öznenin anlam üretimine sunacağı katkı her koşulda saklı kalsa da metin çoğul okumalara fazla açık gözükmemekte, anlatımda farklı bakış açıları kullanılmamakta, geri dönüşlere ya da öncelemelere yer verilmemekte, metnin içinde karmaşık bilmeceler de bulunmamaktadır. Öte yandan, eklenecek her bir çözümleme yöntemi, çalışmanın kapsamını genişleteceğinden, yer kısıtı da devreye girmektedir. $\mathrm{Bu}$ nedenle, bu çalışma özelinde çeviriye ışık tutması açısından yapılacak göstergebilimsel çözümleme, metin kesitlenmesi ve gerçeğe uygunluk (olmak/görünmek) durumlarının değerlendirilmesi, yerdeşlikler, sözleşmeler ve eyleyenlerin kipsel donanımlarının incelenmesi yöntemleri ile sınırlandırılmıştır.

\section{Göstergebilimsel Çözümleme}

"Kesitleme, metni daha kolay ele alınacak, mutlak olmayan birimlere bölmeyi amaçlayan ilk deneysel adım olarak kabul edilir" (Greimas, Courtés, 1982, 270). Metnin daha kolay ele alınmasının göstergebilimsel açıdan getirisi metindeki göstergelerin gözden kaçırılmamasını ve böylelikle daha kolay işlenmesini sağlaması olarak ifade edilebilir. Kesitlenen birimler mutlak değildir; zira kesitleme ölçütleri kesitlenen metnin özelliğine göre belirlenebildiği gibi, çözümlemeyi yapanın bakış açısına ve seçimine göre de değişebilir. Ancak genel olarak "anlatıcı değişimi, bakış açısı değişimi, kahramanların değişimi, zamansal değişim, uzamsal değişim, mantıksal değişim (metnin mantığında bir dönemeç) ya da duyuşsal değişim (kahramanların ruh durumunda bir kırılma) (Öztürk Kasar, 2009, 166) kesitlemede kullanılan ölçütlerdir. Bu anlamda bir kesitin bitişi ve bir diğerinin başlaması, genellikle bir değişim ya da dönüşüm ile tanımlanabilir. Bu değişim ya da dönüşümlerin, metin için özel önem arz eden ve aslında dikkatli okuru metnin sonucuna doğru yönlendiren özelliktedir.

Kesitleme yapılırken, çözümlemeye ışık tutması açısından her bir kesite özelliğinin ya da anlamının yansıması olabilecek bir ad verilebilir. Bu çalışma kapsamında çözümleyeceğimiz Sunday in the Park, öncelikle dönüştürücü edim olarak değerlendirilebilecek bir durum temel alınarak iki bölüme ayrılmıştır. Dönüştürücü edimin bir bitiş getireceği düşünülerek, ilk kesitin adı NIHAỴT olarak düşünülmüştür. Bitişin başlangıç getireceği düşünülerek, ikinci kesitin adı da BIDDAYET, yani başlangıç olarak belirlenmiştir. İlk kesit dört alt kesitten, ikinci kesit ise sekiz alt kesitten oluşmakta ve öykü toplamda on iki alt kesite ayrılmaktadır. Alt kesitler, metinde yeni bir kişinin etkin olması, mevcut bir kişinin harekete geçmesi ya da dönüşüme uğramasına göre belirlenmiş ve o kişinin o anki durumunu ya da dönüşümünü 
yansıtabilecek bir isim ile tanımlanmıştır. Başka bir deyişle, kesitin ayırıcısı ve dolayısı ile alt kesitin belirleyicisi kim ise, kesit o anki duruma özgü olarak o kişiye atfedilen isimle etiketlenmiştir.

Tablo 1:Kesit ve Alt Kesitler

\begin{tabular}{|c|c|c|c|c|c|c|}
\hline Kesit Adı & $\begin{array}{c}\text { Alt } \\
\text { Kesitler }\end{array}$ & $\begin{array}{l}\text { Alt Kesitlerin } \\
\text { Anlamları }\end{array}$ & $\begin{array}{l}\text { Öykü } \\
\text { kişisi }\end{array}$ & $\begin{array}{c}\text { Kesit Başı/ } \\
\text { Kesit Sonu } \\
\text { (satır no) }\end{array}$ & $\begin{array}{l}\text { Bakış } \\
\text { Açısı }\end{array}$ & Anlatici \\
\hline \multirow{4}{*}{ 1. NİHAYET } & 1. Safiye & Temiz, katışıksız & Kadın & $1-16$ & \multirow{11}{*}{ Kadın } & \multirow{11}{*}{ Üstanlatıcı } \\
\hline & 2. Savlet & Saldırma, ani atılış & $\begin{array}{l}\text { Öteki } \\
\text { çocuk } \\
\text { (Joe) }\end{array}$ & $16-41$ & & \\
\hline & 3. Cabir & $\begin{array}{c}\text { Cebredici, zorla } \\
\text { yaptıran, galip gelen }\end{array}$ & $\begin{array}{l}\text { Öteki } \\
\text { adam }\end{array}$ & $42-47$ & & \\
\hline & 4. Fazıl & Erdemli kimse & Morton & $47-80$ & & \\
\hline \multirow{7}{*}{ 2.BİDAYET } & 5. Raci & $\begin{array}{c}\text { Geri dönen çekilen, } \\
\text { kaçan }\end{array}$ & Morton & $81-95$ & & \\
\hline & 6. İfakat & $\begin{array}{c}\text { Ayılma, bayginlıktan } \\
\text { kurtulma }\end{array}$ & Kadın & $96-101$ & & \\
\hline & 7. Bürhan & Kanit, delil, ispat & Morton & $102-111$ & & \\
\hline & 8. Azade & $\begin{array}{c}\text { Bağlardan kurtulmuş, } \\
\text { hür }\end{array}$ & Kadın & $111-118$ & & \\
\hline & 9. Bahire & Belli, açı & Kadın & $119-121$ & & \\
\hline & 10. Hâkime & $\begin{array}{l}\text { Yargılayan, hüküm } \\
\text { veren }\end{array}$ & Kadın & $122-127$ & & \\
\hline & 11. Müzekker & Eril, maskülen & Morton & $128-133$ & & \\
\hline
\end{tabular}




\begin{tabular}{|l|l|l|l|l|l|}
\hline & 12. Kamile & Eksiksiz, kemale ermiş & Kadın & $134-136$ & \\
\hline
\end{tabular}

$\mathrm{Bu}$ çalışmada çözümleme için kullanacağımız diğer bir yöntem olan gerçeğe uygunluk durumlarının (olmak/görünmek) değerlendirilmesi için, Algirdas Julien Greimas ve Joseph Courtés tarafından oluşturulan göstergebilimsel kareye bakabiliriz (1979, 419). Bu karede, olmak/görünmek (olduğu gibi görünmek/göründüğü gibi olmak) durumu "gerçeklik", olmamak/görünmemek (olmadığı gibi görünmemek/görünmediği gibi olmamak) durumu "yanlışlık", olmak/görünmemek (olduğu gibi görünmemek/görünmediği gibi olmak) durumu "giz" ve olmamak/görünmek (olmadı̆̆ı gibi görünmek/göründüğü gibi olmamak) durumu ise "yalan" olarak konumlanmaktadır.

Bu eşleşmelerin her birinin birer olasılık olarak akılda tutulması, görünen ile olanın birbiri ile ne kadar bağdaştığının saptanması yazınsal yapıtın çözümlenmesine ışık tutabilir, yapıt adım adım bu gözle okunduğunda, söylenenlerin ardında söylenmeyen ancak olan, söylenmeden söylenen, söylenen ancak söylendiği gibi olmayan farklı durumları okumak mümkün olabilir.

Çalışmanın bu aşamasında, yapılan kesitleme sonucunda saptanan kesit ve alt kesitler çözümlenerek gerçeğe uygunluk durumları değerlendirilecektir.

\section{1. Safiye - (Kadın) - 1. Kesit / 1. Alt Kesit}

Özet: Bir Pazar günü akşamüstü saat beș buçukta, üç kişilik bir aile neredeyse boş bir parkta vakit geçirmektedir. Adam gazete eki, karısı kitap okumakta, 3 yaşındaki oğulları Larry ise kum havuzunda oynamaktadır. Adamın adı Morton'dır. Eli karısmın omzundadır, kadın huzurlu ve mutludur. Adamın yüzü hafta boyu o gri, fabrikayı andiran üniversiteye tıkılmaktan solgundur. Kadın daha çok dışarı çıkmaları gerektiğini düşünür, Morton'ın kolunu sevgiyle sıkar. Larry'nin yanında başka bir çocuk oynamaktadır. Larry kazmakta olduğu tünele yoğunlaşmıştır.

Öyküde sözü edilen kadın genç olabilir, en azından yaşlı değildir; çünkü 3 yaşında çocuğu vardır. Kadının bir adı yoktur, büyük olasılıkla bir meslek sahibi de değildir ya da en azından çalışmamaktadır, zira Morton üniversiteye tıkılırken kadının daha farklı bir iş ile uğraştığına dair bilgi verilmemektedir. Kadın muhtemelen çalışma ortamının ve şehrin stresine yakalanan Morton'ın hayatını yaşamaktadır. Parkta nefes almakta ve mutluluk aramaktadır. Kadın, kendini adeta mutlu hissetmeye zorlar hâli, bir miktar "saf"3 olduğunu düşündürebilir.

Larry ile bir kum havuzundaki diğer çocuk şimdilik kendi halindedir. Yan yana oynamalarına rağmen aralarında henüz bir iletișim yoktur. Burada söz konusu olan, "çocuğun bir arkadașı ile birlikte aynı gereçleri hemen hemen aynı biçimde kullanarak, ancak etkin bir işbirliği kurmadan ve ortaklaşa bir amaç gütmeden oynadığ 1 oyun türü"4, koşut oyun olarak adlandırılır. İsviçreli Psikolog Jean Piaget'ye göre çocukların oyunlarının birbiriyle çakışmaması birbirlerinin oyununa karışmamaları ve organize olmamaları yaşları gereği benmerkezci olmalarından kaynaklanmaktadır. 5

3 1. alt kesit adı, Safiye.

4 Büyük Türkçe Sözlük, http://www.buyukturkcesozluk.net/arama.php?kelime=ko\%FEut+oyun, [12.03 2016].

5 Nedir Ne Demek NND Sözlük, http://www.nedirnedemek.com/paralel-oyun-nedir-paralel-oyun-ne-demek [12.03.2016] 
Buna göre ilk kesitte her şey yerli yerinde ve olması gerektiği gibi görünmektedir. Ancak öyküyü oluşturmak ve devamını sağlamak için bu tabloyu bozacak, taşları yerinden oynatacak bir etkene gereksinim vardır.

\section{Gerçeğe uygunluk:}

Görünen: Mutlu aile tablosu.

Olan: Çok da mükemmel olmayan aile ilişkileri.

Görünen: Kadın çok mutludur, kocasının kolunu sevgiyle sıkmaktadır, kocasına sevgi ile bağlıdır.

Olan: Kadının hayatı pek parlak değildir. Parkta bir Pazar günü geçirmeyi bile gözünde fazla büyütmektedir, bu durum hayatının tekdüze olduğuna ve pek de ilginç bir şey yaşamadığına bir işaret olabilir. Adeta kendini mutlu hissetmek için şartları zorlamaktadır. Açı olarak ifade edilmese de Morton'ın işi ile ilgili belki de "bilinçaltı" görüşü olumlu görünmemektedir. Daha çok dışarı çıkmaları gerektiğini düşünmesi, yeterince dışarı çıkmadıklarını, Morton’ın ailesi ile yeterince ilgilenmediğini düşündürmektedir.

Öyküde Morton solgun olarak tanımlamakta, soluk bir beniz ve ise kuvvetli bir kişi ya da kuvvetli bir kişilikten çok, zayıf bir kişi ve zayıf bir kişiliği çağrıştırmaktadır. Öyküde Morton'a ilişkin herhangi bir fiziksel çekicilik unsurundan söz edilmemektedir. Öykünün kadının bakış açısından anlatıldığını düşünecek olursak, kocasının dış görünüşünü de aslında pek beğenmediği sonucuna varabiliriz.

Öykünün daha ilk paragrafında olumlu görüntü vermek için seçilmiş ifadelerin arasında sıkışıp kalan Morton'ın soluk benzi ya da fabrikaya benzeyen gri üniversitesi ile her şeyin pürüzsüz olmadığına dair ipucu verilmekte ve bu bilgilerle sona olta atılmaktadır. Sona olta atma, yazarın metin içinde olayın sonuna yönelik üstü kapalı ipuçları vermesidir. ${ }^{6}$ Genette’e göre, 'sona atılan olta' metnin içinde anlamsız ve hatta belirsiz bir tohumdan ibarettir; tohum olarak değeri de ancak daha sonra, geçmişe dönmek suretiyle anlaşlacaktır" (Genette, 1972, 112). Bu nedenle, ilk paragrafta sözü geçen Morton'a dair kimi özelliklerin de ileride bir şekilde sorun olabileceğine ilişkin ipucu aslında okura önceden örtük olarak verilmektedir. Ancak sona atılan oltaların fark edilip edilmemesi, okurun metne nasıl yaklaştığına ve onu nasıl okuduğuna göre okurdan okura farklılık gösterecek bir durumdur.

\subsection{Savlet - (Joe) - 1. Kesit / 2. Alt Kesit}

Özet: Öteki çocuk aniden ayağa kalkar ve Larry'ye bir kürek dolusu kum savurur. Kum Larry'nin kafasın sskalayıp geçerken, Larry de kazmaya devam eder. Kadın çocuğa yapmaması yönünde ikazda bulunurken, gözleri çocuğun annesini ya da bakıcısını arar. Parkta kalan diğer kişiler, iki kadın ve patenli küçük kız, kapıdan çıkmaktadırlar; birkaç metre ötede bankta iri yarı bir adam oturmakta ve gazetenin karikatür ekini yüzüne yakm tutmakta ve adeta bankın tamamım kaplamaktadır. Kadın, adamın çocuğun babası olduğunu düşünür. Adam, kafasını dergiden kaldırmaz ama ağzının kenarından bir tükürük firlatır. O surada, öteki oğlan Larry'ye bir kürek kum daha savurur. Bu sefer kumun bir kısmı saçına ve alnına gelir. Larry ağlayıp ağlamamaya karar vermek için annesinin yüzüne bakar. Kadını aklına ilk gelen, oğlunun yardımına koşmak ve diğer

6“Sona olta atma”, Gérard Genette’in Figures III adlı yapıtında, Raymonde Debray'den alınarak kullanıldığı 'amorce' terimine karşılık olarak Sündüz Öztürk Kasar tarafından önerilmiştir.

Kırklareli Üniversitesi, Fen Edebiyat Fakültesi, Türk Dili ve Ede Bölümü, Kayalı Kampüsü-Kırklareli/TÜRKİYE e-posta: editor@rumelide.com
Adress

Kirklareli University, Faculty of Arts and Sciences, Department of

Turkish Language and Literature, Kayalı Campus-Kırklareli/TURKEY

e-mail: editor@rumelide.com 
çocuğu cezalandırmak olur ama kendini tutar zira daima Larry’nin kendi başının çaresine bakmasımı istemektedir. Ancak öteki çocuğu sertçe uyartr.

\section{Gerçeğe uygunluk:}

Görünen: Larry'nin iyi aile çocuğu ve Joe da aile terbiyesi almamış bir çocuk olduğudur.

Olan: Çocuklar çocuktur ve bazen birbirlerini tanıyan ya da tanımayan çocuklar, birbirlerine nedensiz yere kum ya da başka bir şey atabilirler, hatta vurma ya da ısırma gibi fiziksel zarar verme boyutuna varan davranışlar sergileyebilirler.

Bu durumda öteki çocuğun Larry'ye kum atmasında belki de büyütülecek bir şey yoktur, belki öteki çocuk yaşının getirdiği bir tepki olarak bu davranışta bulunuyordur. Öte yandan, çocuk Larry'nin ya da çevredeki diğer kişilerin dikkatini çekmek için böyle davranıyor olması da olasıdır. Belki de Larry'nin kendisiyle hiç ilgilenmemesini hazmedemediğinden bu "saldırı"7 ile ilgi toplamayı amaçlıyor da olabilir.

Görünen: Kadın öteki çocuğu olumsuz davranışı tekrarlamaması yönünde sertçe uyarmaktadır.

Olan: Kadının Larry'nin kendi başının çaresine bakmasını istemesinin nedeni, belki de gerektiğinde de zorba ile zorba, kavgacı ile kavgacı olmayı bilmesini, kendini korumayı becermesini umması ve aslında Joe'nun olumsuz özelliklerinden bazılarının Larry'de de olmasını beklemesidir.

Kadın, öncelikle çocuğun annesini ya da bakıcısını aramakta, çocuğu parka babasının getirmiş olabileceği olasılığı aklına hiç gelmemektedir. Bu durum, çocukları parka anneleri ya da bakıcıları getirdiği ya da en kötü ihtimalle anne ve babaları birlikte getirdiği, ancak babalar tek başına getirmediği yönündeki genel kabulden kaynaklanabileceği gibi, kadının kendi aile yaşantısındaki alışkanlıklardan ileri gelen bir koşullanma da olabilir.

Kadın, birçok annenin yapabileceği gibi, çocuğunu öteki çocuk ile karşılaştırmaktadır. Öteki çocuk, Larry'ye göre fiziksel olarak daha gelişmiştir, ancak kadın kendi çocuğunda da öteki çocuğa göre daha üstün yönler aramakta ve bulmaktadır. Örneğin Larry, öteki çocuktan daha hareketli, daha hassas, öteki çocuk ise hantaldır. Kadın, kendi çocuğunun ötekinden üstün olduğunu en azından öncelikle kendi aklında kendine kanıtlamaya çalışmaktadır. Ancak öteki çocuk, Larry’ye göre daha bağımsız ve etkin bir görüntü sergilemekte, Larry saldırıya uğradığında ağlayıp ağlamayacağına bile annesinin tepkilerine göre karar verirken, niyeti ne olursa olsun öteki çocuk tamamen kendi kararıyla iyi ya da kötü bir iletişimi başlatmak amacıyla harekete geçmektedir.

Çıkan soruna ve Larry'nin annesinin hemen işe karışmasına rağmen, çocukla birlikte gelen kişi her kimse ses çıkartmamıştır. Ancak, bankta oturan adamın, kafasını dergiden kaldırmasa da tükürmesi, olayla ilgilenmiyor görünse de aslında olan bitenin farkında olduğunu ve olan bitenden belki de pek hoşlanmadığı göstermektedir, çünkü tükürmek, gerek birincil anlamı itibarı ile, gerekse içinde yüklü alt anlamlar bakımından daima olumsuz çağrışımlar yüklü bir edimdir. İçerdiği anlamlardan bazıları, aşağılama, küçümseme, hor görme, kabalık, zorbalık saygısızlık, hiçe saymak olarak sıralanabilir. Öte yandan, adamın "çabucak" ya da "ustalıkla" tükürüyor olması da, aslında bunu sık sık yaptığına işaret olup, mizacının böyle bir davranışa uygun olduğunu da göstermektedir. Adamın bütün bankı

7 2. alt kesit ad, Savlet. 
kaplamış olması ise, hem cüssesinin iriliğinden kaynaklanmakta olup, hem de oturduğu yere bu kadar yayılabilmesi için bacaklarını açıp oturması gerektiğinden, vücut dilinin bir tür küstahlığa ya da etrafı hiç umursamama haline işaret ettiği düşünülebilir.

\section{3. (Öteki adam) - Cabir - 1. Kesit / 3. Alt Kesit}

Özet: Banktaki adam, sanki tekrar tükürecekmiş gibi ağzını oynatır fakat bu sefer tükürmek yerine konuşur. Oğluna aynen devam etmesini söyler. Kum havuzu herkesindir. Kadın, Morton'a baktığında dizlerinde ani bir dermansızlık hisseder. Morton olup biteni fark etmiştir.

$\mathrm{Bu}$ alt kesitte, banktaki adamın olaya dâhil olması ile, öteki çocuğun muhtemelen babası olduğu, ya da en azından çocuğu parka getiren kişi olduğu anlaşılmıştır. Adam, kadın ile hiç muhatap olmadan, doğrudan kendi çocuğu ile konuşmaktadır. Kadın da adamla muhatap olmayı düşünmemekte, doğrudan kocasına bakmaktadır. Neden adama kadın karşılık vermeyip, kocasının vermesi gerektiği gibi bir beklenti içine girmiştir? $\mathrm{O}$ ana kadar konuşan kadındır, ancak şimdi kocasına bakarak onu bir şekilde bu işe karıştırmaktadır. Bunun bir nedeni adamın kadını yok sayıp çocukla konuşması, diğer bir nedeni de, çocuğun annesi ya da bakıcısıyla karşılaşmayı beklerken karşısında bir erkek bulmus olması olabilir. Bu durumun, bir erkeğin muhatabı başka bir erkek olmalıdır, önkabulünden kaynaklandığı düşünülebilir.

Ĕ̆er öteki çocuğun yanında annesi olsa, kadın onunla muhtemelen daha rahat iletişim kurabilecektir. Öte yandan, eğer çocuğun yanındaki annesi olsa, bir annenin "aynen devam et, ne istersen at" demesi daha az inandırıcı olurdu. Bir kadının çocuğunu saldırganlığa teşvik etmesi çok alışılmış bir durum değildir, oysa bunu bir erkek yaptığında, oğluna gerektiğinde saldırmayı ya da kendini korumayı öğrettiği düşünülebilecek ve durum daha az şaşırtıcı olacaktır.

İlginç olan bir nokta da, bir önceki alt kesitte, Larry'nin annesinin hemen işe karışıp öteki çocuğa müdahale etmesi, buna karşılık öteki adamın ilk anda sessiz kalıp sadece yere tükürmekle yetinerek, olaya dâhil olmak için bir müddet daha sabretmesidir. Öteki adam muhtemelen çocuğunu gözlemlemeye devam etmesine rağmen, illa gerekli değilse çocuğuna karışmamakta, onu belli ölçülerde serbest ve bağımsız bırakıp, olaylarla ve sorunlarla tek başına mücadele etmesine olanak tanımaktadır.

Öte yandan öteki adam, çocuğunun kum atması konusunda, kum havuzunun kimsenin tekelinde olmadığını, herkese açık bir kum havuzu olduğunu ve Joe'nun da Larry kadar hakkı olduğunu söylemektedir. Aslında Morton ya da karısı da Joe'nun oyun oynama hakkı konusunda aksini iddia etmemektedir, ancak öteki adam saldırganlığa dönüşmüş bir haksızlığa uğrama kaygısı içindedir. Adamın konuşurken kullandığı üslubun yanı sıra beden dili de kaba sabadır. Bu durum, onun Morton ve ailesine göre farklı bir çevreden geldiğini düşündürmektedir. Belki de adamı bir tür aşağılık kompleksi yönlendirmektedir.

Öteki adam, çocuğunun kum atmasına engel olmadığı gibi, aksine destek çıktı̆̆ında ve Morton da bu durumu fark etiğinde, kadının dizlerinde derman kesilmiştir. Dizlerde derman kesilmesi, ya da dizlerin bağının çözülmesi, genellikle korku ile ilintili durumlardır. Peki kadın neden korkmaktadır? Karşısında saldırganlığı teşvik eden, fiziksel ve davranışsal yönden kaba saba olan bu adamın kendisinden mi korkmaktadır, yoksa durumu fark eden Morton'ın bu adam karşısında düşeceği durum mu kadını endişelendirmektedir? 


\section{Gerçeğe Uygunluk:}

Görünen: Kadın, büyük bir kavga çıkı, her iki tarafın da zarar görmesinden, ya da taraflardan şu anda belli olmayan herhangi birinin zarar görmesinden korkmakta ve bu nedenle dizlerinin bağı çözülmektedir.

Olan: Kadın, şu ya da bu şekilde Morton'ın yenilen taraf olacağından emindir. Kadın, kocasını iyi tanımaktadır ve ne yapabileceğini de, ne yapamayacağını da son derece iyi bilmektedir, bu nedenle kadının dizlerinin bağının çözülmesi olacaklardan korkması kadar, olacakların nelere neden olacağını öngörmesindendir.

Başka bir deyişle, kadının bu korkusu, öyküde sona atılmış bir başka oltadır. Kadın kocasının dayak yemesinden mi korkmaktadır, yoksa bilinçaltında gizli bir takım rahatsızlıkların bu olay aracılığıyla açığa çıkmasından mı çekinmektedir? Kadın, öteki adam ile Morton'ın farklı kulvarlarda olduğunu öteki adamın verdiği tepkiden derhal çözmüştür. Öteki adam, fiziksel özellikleri ile de desteklenen bir zorba, zorluk çlkaran, "zor kullanan" gömleği giymiştir. Kadın bunu gördüğü andan itibaren işlerin de kontrolden çıkmakta olduğunu anlamıştır.

\subsection{Fazıl - (Morton) - 1. Kesit / 4. Alt Kesit}

Özet: Morton, adamla mantıkh bir konuşma yapmaya yeltenir ancak adam Morton'in sözünü keser. Adama göre, kendi çocuğunun da orada bulunmaya hakkı vardır ve canı kum atmak isterse de atacaktır. Bu Morton'ın hoşuna gitmezse de, Morton çocuğunu alıp oradan cehennem olacaktur. Morton yine konuşmaya çalışır ama adam onu yine susturur. İki adam da yerlerinden kalkar. Kadın, bir şey yapmak, onları durdurmak kocasın tutup geri çekmek ister, ancak nedense yapmaz. Morton "Sorartm size,...." diye yeniden bir cümleye başlayacak olur, adam yine onu susturur. Adama göre Morton tek başına soru bile sorabilecek biri değildir. "Hadi ya ?”, der. "Sen mi? Kaç kişi ile?”

Morton: Yükseköğrenim görmüss, bir üniversitede muhtemelen öğretim üyesi, düşüncelerini düzgün bir dille ifade edebilen, bütün hafta ofisin içine tıkılmaktan cildi güneş görmeyen, çok kuvvetli olmayan, muhtemelen kendinden farklı hitabet tarzı olan kişilere kolay kolay uyum sağlayamayan, tartışmak yerine kavga çıkarmayı tercih eden muhatabı üzerinde de etkili olamayan bir kişidir. "Erdemli" 9 davranıș biçimlerinin her zaman işe yaramadığının bir örneği ve yerine göre davranabilmenin de aslında önemli olduğunun tersine örneğidir. Ummadığı bir tepki ile karşılaşınca "bir dakika" diyerek zaman kazanmakta, adam onu susturunca acizliğinin bir sonucu olarak o an ne yapacağını ve hatta ellerini nereye koyacağını bilemediğinden gözlüklerini düzeltmektedir.

Öteki adam: İri cüsseli, kaba saba, gittiği her yerde kavga çıarıp sorun yaratabilecek tiplerdendir, düşmanca bir tavır sergilemektedir. Mizah dergisini neredeyse yüzüne yapıştırıp okumasının pek de eğitimli olmadığına işaret ettiği düşünülebilir. Morton ile arasında bir güç savaşı ve yumruk yumruğa girişilecek bir ortam yaratmaya çalışmaktadır. "Sen mi?" sorusu ile, öteki adam Morton'u sifırlamakta, adam yerine dahi koymadığını bir kere daha belli etmektedir.

\section{Gerceğe uygunluk:}

Görünen: Kadın kocasını durdurmak ve bir kavga çıkmasını engellemek istemektedir.

${ }^{8}$ 3. alt kesit adı, Cabir.

9 4. alt kesit adı, Fazıl. 
Olan: Kocasını durdurmamakta ve durdurmak da istememektedir, çünkü içinde gizliden gizliye bir kavga çımasını, bu kavgada da kocasının öteki adamın hakkından gelmesini ve kavgadan galip çımasını istemektedir. Öteki adamın haksız olduğunu kabul etmesi için yenilmesi gerekmektedir.

Görünen: İki aile farklı sosyal çevrelerden gelmektedirler ve bunun bir sonucu olarak birbirlerini anlamakta zorlanmaktadırlar.

Olan: Görünende gerçek payı olsa da hayatta bazı insanlar kendilerine etraflarındakileri terbiye etme gibi bir misyon yüklerlerse, bazıları da asla başkalarının doğruları ile terbiyelenmemeyi ilke edinebilirler; zira hayatta mutlak doğrular olmayabilir, birine göre yanlış olan diğerine göre o kadar da yanlış olmayabilir.

Görünen: Morton adamın seviyesine inerse kavga çıkacaktır ve onun seviyesine inmemek için de geri çekilmelidir.

Olan: Geri çekilirse onuru ciddi bir şekilde zedelenecek, gerçi geri çekilmezse de çıkan kavgada mutlaka dayak yiyeceği için yine onuru zedelenecektir. Kısacası Morton'ın pek şansı bulunmamaktadır.

Görünen: Kadın Morton’ın nezaketinden memnun, ona karşı şefkat beslemektedir.

Olan: Kadın, diğer yandan da Morton'ın maskülen olmasını, yerine göre davranmasını istemektedir. Kadının ihtiyaçları ve değerleri birbiriyle çatışmaktadır. Bir yandan kocasının düzgün davranması olumlu bir özellik gibi görünürken, diğer yandan da içten içe kocasının ailesini ve onurunu korumak için gerekirse güç kullanmasını istemektedir. Yaşadığı bu çelişki, belki de evliliğini açısından bir tehdide dönüşecektir.

Görünen: Kadın, Morton'u hiç de alışkın olmadığı nahoş bir duruma düşürdüğü için öteki adama karşı öfke duymaktadır.

Olan: Kadın, öteki adama kocasının zayıflığını apaçık ortaya döktüğü için öfke duymaktadır.

Bu noktada, yapmış olduğumuz kesitlemeye göre, dördüncü alt kesitin sonu ile NİHAYET adını verdiğimiz ilk kesitte sona ermekte ve BİDAYET adlı ikinci kesit başlamaktadır. İlk kesitin sonu ve ikinci kesitin başlangıcının, Morton ve karısının yaşamlarında da bir evrenin sonu ve başka bir evrenin başlangıcı olarak yansıyabileceği düşünülebilir.

\subsection{Raci - (Morton) - 2. Kesit / 5. Alt kesit}

Özet: İki adam birbirlerine dik dik bakar. Morton parktan gitmeye karar verir, kum havuzuna yürür, Larry'yi ve küreğini kaldırtr. Larry tekme savurup ağlamaya başlar. Eve gitmek istememektedir. Anne baba ayak direyen çocuğu çekiştirir. Çıkış kapısına ulaşmak için adamın hala tükürüp yayıldığı bankın oradan geçmek zorunda kalırlar. Kadın, adama bakmamaya özen göstererek kocası ve çocuğuyla oyun bahçesinden çıkar.

Bu noktada Morton "rücu”'ı etmekte, yani geri çekilmekte, geri adım atmaktadır.

\section{Gerçeğe uygunluk:}

Görünen: Morton adamın seviyesine inmeden oradan uzaklaşmaktadır.

${ }^{10} 5$. alt kesit adı, Raci. 
Olan: Morton, yenildiğinin ve bunun sonucunda düşmüş̧ olduğu durumun o kadar farkındadır ki herkes ona bakıyormuşçasına sendelemekte ve ayakları dolaşmaktadır.

Görünen: Morton adamın seviyesine inmeden oradan uzaklaşmaktadır.

Olan: Morton doğru bildiğini savunmak yerine kaçıp giden bir korkaktır. Öteki adam için ise başkalarının ne düşündüğü değil, kendisinin ve oğlunun şerefi önemlidir.

Görünen: Morton adamın seviyesine inmeden oradan uzaklaşmaktadır.

Olan: Öteki adam, "Beğenmezsen sen de çocuğunu alır buradan cehennem olursun" demiştir ve nihayetinde de onun dediği olmakta, Morton karısını ve çocuğunu alıp, yani tası tarağı toplayıp orayı terk etmek zorunda kalmaktadır.

Görünen: Tüküren, kaba saba konuşan, zorba tutumlar sergileyen öteki adam, çocuğu için iyi bir rol model değildir.

Olan: Morton da çocuğu için mükemmel bir rol model değildir; çünkü erkeksi bir baba modeli değildir, korkup kaçmaktadır, karısını ve çocuğunu savunmamaktadır. Karşısındaki adama hiçbir şekilde hükmü geçmezken, karısına ve çocuğuna parktan gideceklerini tebliğ etmektedir. Yani bir yandan yabancıların karşısında son derece aciz kalıp ezilirken, karısı ve çocuğunun yanında evin reisini oynamakta ve evin karar alma yetkilisi olma özelliğini aklınca sürdürmeye kalkışmaktadır. Eve gitmeye Morton karar vermektedir, kadının bu konuda söz hakkı bulunmamaktadır.

Babası her şartta Joe'nun arkasında durmaktadır, üstelik çocuğunu bizzat parka getiren bir babadır, bu nedenle bir bakıma da ilgili bir baba olduğu düşünülebilir. Kendince Joe'nun parkta oynama hakkını korumaktadır. Tüm kabalığına rağmen çocuğuna asla kötü davranmazken, kibar Morton oğlunu ağlata ağlata, ayaklarını yerlerde sürüye sürüye zorla parktan çlkarmaktadır.

\section{6. İfakat - (Kadın) - 2. Kesit / 6. Alt kesit}

Özet: Kadın önce kavga çıkmadiğı kimse de zarar görmediği için bir rahatlama hisseder Fakat bu duygunun altında, ağır, kaçınılmaz, keyif kaçırıcı bir olaydan da öte, farklı bir his daha vardır. Kadın, bunun kendisi ve Morton ile ilgili olduğunu belli belirsiz sezinler.

Kadının ruhsal dönüşümü burada gerçekleşmektedir. Kadın açısından dönüştürücü edim, Morton'ın öteki çocuğun babasının karşısındaki aciz tutumudur. Kadın, aslında belki de sessiz ve derinden bildiği gerçeklere burada "uyanmakta ve ayllmaktadır" 11 Aslında bunun kadın için bir dönüştürücü edim olması, Morton için de bir dönüştürücü edim olması ile sonuçlanacaktır. Öte yandan bu durum muhtemelen çocuk için de bir takım sonuçlar doğuracağından, çocuk açısından da dönüştürücü bir edim olarak düşünülebilir. Ancak, bir aileyi derinden etkileyecek bu durumun, olayın diğer paydaşları olan öteki adam ve Larry için herhangi bir sonucu bulunmamaktadır.

\section{Gerçeğe uygunluk:}

Görünen: Kadın bir rahatlama hissi içerisindedir.

11 6. alt kesit adı, İfakat. 
Olan: Kadın, ruhsal bir dönüşüm, acı bir farkındalık, hem ağır gelen ve hem de ağrına giden bir gerçek ile karşı karşıyadır. Belki de bu durum önceden içten içe bildiği bir şeyin aşikâr olması, yani malumun ilan edilmesi ile ilgilidir.

Kadın, belki de bir rahatlama ya da ferahlama hissi duymak için ve başka türlü düşünmemek adına kendini zorlamakta, ama bu bir işe yaramamakta ve aslında bu olayın hiç de hoşuna gitmediğini, Morton'ın bu olay yüzünden gözünden düştügünü hissetmeye başlamaktadır. Bu noktada bir çeşit uzaklaşma ve soğuma hissine kapılmıştır. Bu duygunun kişisel ve önemli olduğunu da teşhis etmesi bir yana, duygunun aynı zamanda "bilindik" ya da "tanıdık" olarak tanımlanması da ayrıca ilginçtir, zira bu tanımlamalar kadının zaten böyle bir şeyi önceden de hissetmiş olduğunu düşündürmektedir, bu da bilinenin aşikâr edilmesi, malumun ilan edilmesi ya da malumun teyit edilmesi olarak tanımlanabilir.

\subsection{Bürhan - (Morton) - 2. Kesit / 7. Alt kesit}

Özet: Morton aniden konuşmaya başlayarak, aslında öteki adamla kavga etmesinin ashnda hiçbir işe yaramayacağını karısına kantlanmaya çalışır. Morton, kavga etmemekle ne kadar iyi yaptığın kanıtlayacak deliller sunmakta, kadın ise onun her dediğini "Tabi" diyerek geçiştirmektedir.

\section{Gerçeğe uygunluk:}

Görünen: Morton, oradan çekip gitme kararını vermesinin en doğrusu olduğunu "ispat"12 etme derdindedir.

Olan: Morton, aslında öteki adam karşısındaki acizliğini ve gerçekte oradan kaçmak zorunda kaldığını, aksi halde neler olacağına dair somut örneklerle "ispat”"ederek karısının gözünde iyice küçülmektedir.

Görünen: Karısı, Morton’ın açıklamalarına katılmaktadır, “tabi” diyerek onu onaylamaktadır.

Olan: Morton ve söylediklerinin önemi git gide azalmakta, kadın "tabi" diyerek kocasını geçiştirmektedir.

Morton kendi sözleri ile kendini iyice batırmakta, eğer orada kalsa adamdan dayak yiyeceğini itiraf etmektedir. Hatta dişlerinin ve gözlüğünün kırılacağını ve bir iki gün işe gidemeyeceğini söylemekle, adamın onu sadece döveceğini değil, fena döveceğini, hatta hastanelik edeceğini de söylemiş olmaktadır, zira işe gitmemek için muhtemelen iş görmez raporu alması gerekecektir. Kadın, Morton'ın açıklamalarını duysa da, aslında artık dinlememekle ve "”tabi, tabi”’ diyerek savuşturmaktadır.

\subsection{Azade - (Kadın) - 2. Kesit / 8. Alt kesit}

Özet: Kadın, adımlarım hızlandırır. Tek istediği eve varmak ve her zamanki işlerle kendini oyalamaktır. Çocuk hala ağlamaktadır. Çocuğa karşı her zaman şefkat duyan kadının şimdi öfkeden çenesi kilitlenmektedir.

12 7. alt kesit adı; Bürhan. 


\section{Gerçeğe uygunluk:}

Görünen: Kadın, oradan uzaklaşıp olanları unutmak, oradan ve Morton'dan ve de her şeyden "azat"13 olmak istemektedir.

Olan: Olanların unutulması ya da yok sayılması imkânsızdır.

Kadının şahit olduklarına Morton'ın pişkince ettiği "dayak yerdim” itirafı eklenince, durum iyice içinden çıkılmaz bir hal almaktadır. Kadın, adımlarını hızlandırmakla, sadece olay yerinden değil, belki de Morton'dan da kaçmaktadır. Artık gözü çocuğunu dahi görmemektedir. Eğer bu evliliği şimdiye kadar ayakta tutan çocuk ise, şu andan itibaren onun da eski önemi kalmamıştır.

\subsection{Bahire - (Kadın) - 2. Kesit / 9. Alt kesit}

Özet: Kadın çocuğa ağlamayı kesmesini, ondan utandığını söyler. Çocuk daha yüksek perdeden ağlar.

\section{Gerçĕge uygunluk:}

Görünen: Ağlamak bir acizlik göstergesi olduğu için, kadın çocuğundan utanmaktadır.

Olan: Kadın aslında sadece çocuktan değil, hatta belki de çocuktan değil, çocuğun babasından utanmaktadır, zira oradaki tek aciz kalmış kişi ya da asıl aciz kalmış kişi çocuk değildir. Ancak, kadın şimdilik bunu telaffuz etmemekte, yine de aslında çocuğun şahsında, adama da bağırmaktadır. Hatta aslında adama bağırmaktadır; çünkü adamın da sesini kesmesini istemektedir ve adamdan da utanmaktadır. Başka bir deyişle, kadın şimdilik sadece çocuktan utandığını "açı"” etmekte, ancak asıl adamdan utandığını henüz belli etmemektedir.

\subsection{Hâkime (Kadın) - 2. Kesit / 10. Alt kesit}

Özet: Kadın olayı içinden değerlendirmektedir. Kavgaya değecek bir konu olsa diye düsünür. Morton aslında ne yapmalıdır? Olup biten aptalcadır, üzerinde düşünmeye bile değmemektedir.

\section{Gerçeğe uygunluk:}

Görünen: Kadın, olayın kayda değerliğini sorgulamaktadır.

Olan: Kadın, Morton’ın kayda değerliğini sorgulamaktadır.

Kadın, yaşadığı uzaklık, soğukluk, aşağılama ve hatta belki de henüz açığa çıkmamış tiksinti duygularıyla, Morton'a dair algılarının ve kabullerinin sarsıldığının gayet farkında, son bir gayretle olayı "muhakeme" 15 etmekte, kafasında Morton'u mazur gösterecek nedenler yaratmaya çalışmaktadır. Morton'u mazur görmeyi başaramasa da olayı saçma ve düşünmeye değmez olarak tanımlayıp, bir bakıma gerçeklerden kaçmak da Morton'u affetmesini sağlayabilecektir. Kadın, bunu da denemekte, olayı kafasından kovmak için kendine çeşitli telkinlerde bulunmaktadır.

13 8. alt kesit adı, Azade.

14 9. alt kesit adı, Bahire.

15 10. alt kesit adı, Hâkime. 


\subsection{Müzekker - (Morton) - 2. Kesit / 11. Alt kesit}

Özet: Morton, sinirli ve eleştirel bir üslupla karısından çocuğu susturmasını ister. Zaten çocuğu susturmaya çalışan kadın da ters bir karşılık verir. Morton karısına, eğer çocuğa terbiye veremiyorsa kendisinin vereceğini söyler ve çocuğa doğru bir hamle yapar.

\section{Gerçeğe uygunluk:}

Görünen: Morton, oğlunun iyi aile çocuğu gibi davranmasına ve terbiyeli olmasına önem vermektedir.

Olan: Morton'ın gücü bir çocuğa yetmekte hatta belki sadece kendi çocuğuna yetmektedir. Morton karısına diklenmekte, kafa tutmakta, kadın ve çocuğa karșı delikanlılık taslamakta, öteki adamın tarzında saldırgan bir "maskülen"16 duruş sergilemeye girişmektedir; ancak kendi ile akran ya da denk saylabilecek adamın yanında hükmü geçmemekte, onun yanında bir hiçe, bir korkağa dönüşmekte, ona yapamadığını karısına ve çocuğuna yapmaya kalkışmaktadır.

Morton karısına "Susturamıyor musun şunu” demektedir. Oysa Morton'ın bu sözlerle bir de demeden dedikleri vardır. Ôrneğin: "Susturması gereken de, susturamayan da sensin. Ben, böyle bir ödevden muafim ve bundan dolayı, çocuğun susturulamamasından kaynaklanan beceriksizlik durumu da tamamen sana ait. Bu çocuğa terbiyesini veremiyorsan, ben veririm. Senin yapamadığını ben yaparım. Aciz olan sensin. Ben aciz değilim.”

Böylelikle Morton, öteki adamın yanında kaybettiği gücünü, karısını ezerek geri kazanmaya çalışmaktadır.

\subsection{Kamile - (Kadın) - 2. Kesit / 12. Alt kesit}

Özet: Çocuğu terbiye edeceğini söyleyerek hamle yapan Morton'u, kadının sesi durdurur. Kendi söylediklerini işitmek kadını da şaşırtır. Kadının sesi incedir, soğuktur, içe işlemektedir ve küçümseme doludur. Morton soru sormak istediğinde onu aşağllayan öteki adamın sözlerini aynen tekrar etmektedir kadın. "Hadi canım?” der. "Sen mi? Kaç kişi ile?"

Görünen/Olan: Böylelikle öykünün sonunda görünen ve olan ikilemi ortadan kakmaktadır. Kadın, içinden geçeni, ne düşünüyorsa onu söylemektedir. Artık her şey göründüğü gibidir.

Kadın: Normalde hiç kendinden beklenmeyecek bir söylem içine girmektedir. Kendine ait olmayan bu söylem ağzından dökülürken, adeta ruhu bedeninden ayrılıp kendini seyretmekte ve dinlemektedir; kadın kendi sesini duymakta, ağzından çıkanlar ve kendi eridiği "kemal"17 kendine bile inanılmaz gelmektedir.

Kadının kullandığı söylem, öteki adamın söylemi, yani öteki adama ait bir metindir. Kadının kocasından ve evliliğinden memnuniyetsizliği artık gizlenemez haldedir, kadın bunu saklayamamaktadır. Bu memnuniyetsizlik, Morton'ın bir başka adamın karşısında aciz kalıp, çocuğunun ve karısının üzerinde güç göstermeye çalışmasıyla, kadın açısından derin bir içerlemeye, hatta belki de ani bir kin duygusuna dönüşmüsstür. Kadın, adama öylesine içerlemiştir ki ona saldırıp canını acıtmaktadır. Bu olay, o ince, soğuk ve aşağılayıcı sesi ile, kadının içindeki kötü kişiyi de ortaya çıkarmaktadır; çünkü olayı hazmedememiştir, kaldıramamıştır ve gururuna yedirememiştir.

16 11. alt kesit adı, Müzekker.

17 12. alt kesit adı, Kamile. 
Kadının evliliği tehlikeye girmiştir, artık bu ilişki sürse de hiçbir şeyin eskisi gibi olamayacağı anlaşılmaktadır; zira kadın, sözleri ile adamı küçük gördügünü belli etmiştir. Gizli kalmış, telaffuz edilmemiş ve kimseye itiraf edilmemiş düşüncelerin ilk kez söze dökülmesi çok önemli bir eşiktir. Kadın kocasına bir kez kötü muamele etti mi artık hep edebilecektir, zira bir şeyi bir kere yapan, hep yapabilir, hele hele kötü bir şeyi bir kere yapmaya cesaret eden, o geçilmemesi gereken eşikten geçmiştir artık ve potansiyel olarak er ya da geç bunu tekrar edebilecektir. Bu yüzden de bazı şeylerin hiç söylenmemesi gerekir, söyleniyorsa da artık oradan gidilmesi, orada durulmaması lazımdır.

İnsanlar fazla değişmez, Morton da hep böyle güçsüz, pasif kalacak, hiçbir zaman güçlü ve korumacı olmayacak, asla kadının düşündüğü adama dönüssmeyecek ve eğer bu evlilik sürerse muhtemelen kadın Morton'a karşı aşağılayıcı söylemlerini devam ettirebileceği gibi, Morton da yüzgöz olduğu ve canını yakan karısına baskın çıkmaya ve onu ezmeye çalışabilecektir.

“Sen mi?” sorusu ile bu kez karısı Morton'u sıfırlamaktadır, başka bir deyişle, Morton aynı zaman dilimi içinde iki kere gururunu kırıcı, onurunu zedeleyici ve kişiliği ile kimliğini aşağılayıcı darbe almıştır.

Öykünün sonunda yorum okura bırakılmaktadır. Buna rağmen ortada büyük bir muamma olduğunu söylemek de çok doğru olmaz. Belki bu evlilik burada bitecek, belki buradan aldığ ağır darbe ve yaralarla bir süre can çekiştikten sonra başka bir nedenle son bulacak, belki de öyle ya da böyle devam edecektir. Ancak evlilik bitse de bitmese de hiçbir şey artık eskisi gibi olamayacaktır. Dolayısı ile her şekilde bu ilişkiye dair bir devir nihayete ermiş ve başka bir devrin bidayeti hâsıl olmuştur.

Öykünün ana sorunsalının aslında Morton ve karısı bağlamında yaşandığından daha önce söz etmiştik. Öykü kesitlenip kesit ve alt kesitlere ayrıldığında bu durum daha belirgin bir biçimde ortaya çıkmaktadır. Mevcut bir kişinin harekete geçmesi ya da dönüşüme uğramasına göre belirlenmiş olan 12 alt kesitin altısında alt kesit adları kadının anki durumunu ya da dönüşümünü yansıtabilecek bir isim ile tanımlanırken, dördü Morton'u biri öteki adamı ve biri de Joe'yu yansıtacak şekilde etiketlenmiştir.

Öyküdeki büyüklü küçüklü engellere dikkatle bakıldığında, aslında Joe ya da babasının çıkardığı sorunların aşılabilir olduğu düşünülebilir, zira her ikisi de üçüncü kişilerdir ve başka insanların hayatlarında ya da ilişkilerinde doğrudan etkilerinin olması beklenemez. Öyle ise burada asıl sorun yaratan adam veya oğlu değil, Morton'ın adama karşı verdiği tepkidir, zira Morton'ın parktan adeta kaçması, kadın için dönüştürücü edim olmuş ve kadının dönüşümü, Morton'ın onu ezme girişimiyle daha da pekişmiştir. Morton başka türlü davransaydı, belki öykü başka bir yöne gidebilecekti. Öte yandan, Morton'ın başka türlü davranmamasının kişiliği ile ilintili olduğu gibi fiziksel özellikleri ile de ilintili olduğu düşünülebilir. Bu noktada, metin içinde oluşan yerdeşlikleri incelemek yararlı olabilir.

\section{Metinde Oluşan Yerdeşliklerin Değerlendirilmesi}

“Algirdas Julien Greimas'ın fizik-kimya alanından göstergebilime taşıdığı yerdeşlik terimi türdeş bir anlama düzlemini ifade eder. Yerdeşlik, ortak anlam özellikleri içeren öğelerin tekrarlanmasıyla kurulur"(Öztürk Kasar, 2009, 169). Burada metin içinde anlam oluşumuna katkıda bulunan tekrarlamalardan, aynı sözcüğün değil, ortak anlam özelliklerini paylaşan sözcük ya da ifadelerin tekrar edilmesi anlaşılmalıdır. Morton, oğlu Larry, öteki adam ve oğlu Joe'nun birbirleriyle tezat oluşturan fiziksel özellikleri öykünün çeşitli yerlerinde tekrar edilmekte ve karakterlerin bu bağlamdaki karşıtlı̆̆ının davranış biçimlerine ve düşünce tarzlarına yansıması kimi zaman doğrudan, kimi zaman da dolaylı olarak ortaya 
koyulmaktadır. Öyküde geçen olayların temelinde aslında bu karşıtlıklar yatmaktadır. Tekrarlanan ortak anlam, Morton ve öteki adamın fiziksel özellikleridir.

Öyküde Morton fiziksel olarak güçsüz olduğu izlenimini verecek sözcüklerle tanımlanırken, öteki adamın iri yarı olduğuna vurgu yapılmaktadır. Morton karısı ile bir bankı paylaşırken, öteki adam bütün bankı kaplamaktadır. Soluk benizli, gözlüklü, ince, narin yüzlü

Morton, öteki adamla konuşurken utangaç, özür dileyen bir tebessüm takınmakta, ancak öteki adamın tepkisiyle rengi iyice solmakta, sendeleyip ayakları dolaşmakta, adamın kendisinden cüsseli olduğunu ve bir kavga halinde ondan dayak yiyeceğini, gözlüklerinin ve dişlerinin kırılacağını birkaç gün işe gidemeyeceğini karısına itiraf etmektedir. Öteki adamın beden dili onun kaba saba bir kişiliği olduğuna işaret etmekte, adam gerek bankta yayılıp otururken dıșarıya verdiği küstah görüntü ile, gerekse kocaman kollarını kavușturup Morton'ın karşısına dikilmesi ve bacaklarını iki yana açıp yaylanmasıyla, Morton'a meydan okuyan ve hatta onu tehdit eden bir görüntü sergilemektedir. Adamın tükürme davranışı da kabalığını teyit eden başka bir durumdur.

Öte yandan, iki adamın oğulları da kendilerine benzer bazı özellikler göstermektedir. Joe babası gibi iri bir çocuktur ve saldırma davranışı göstermektedir. Metinde Joe, gürbüz, şişman, tombul kollu, kayıtsız, ruhsuz, söz dinlemez olarak betimlenirken, Larry, Joe'dan dört beş kilo daha zayıf, küçük savunmasız bedenli, çelimsiz kollu, çizgili, kanat gibi çıııntılı kürek kemikleri, dar omuzları, ince ve dengesiz bacakları olan bir çocuktur. Larry, Joe'nun kum atması karşısında ağlayıp ağlamamaya bile annesinin tepkisine göre karar veren, daha hassas bir çocuk olarak tarif edilmektedir.

Parkta yaşanan sorunların kaynağı aslında fiziksel farklılıklardır. Eğer öyle olmasaydı, bu farklılıklar tekrarlanmak suretiyle vurgulanmazdı. Öte yandan, Morton fiziksel açıdan adamla eşit olsaydı belki de kaçıp gitmezdi ya da adam Morton'a bu kadar kafa tutamazdı. Adam ufak tefek biri olsa idi belki bu kadar küstah ve kaba olmazdı, zira cesaretini muhtemelen cüssesinden almaktadır.

Sonuç olarak öyküde oluşan yerdeşlikler, fiziksel özellikleri ortak anlam olarak kullanan sözcük ya da ifadelerin tekrarlanmasıyla işlev görmektedir. Karşıtlık şeklindeki bu yerdeşlikler öykünün içinde birbirlerini bulup anlam oluşturmakta, fiziksel özelliklerin bazı insanların davranış biçimlerine ve kişiliklerine nasıl yansıyabileceğini ve bunun ne gibi sonuçlar doğuracağını göstererek öykünün anlam evrenine önemli bir katkı sunmaktadır.

\section{Anlatıdaki Sözleşmelerin Anlam Oluşumuna Katkılarının Değerlendirilmesi}

"Sözleşmeler metinde özneler arası yapının biçimlendirilmesinde rol oynar. Sözleşme söz konusu olduğunda, sözleşmeye katılan öğelerin birbirine göre konumunu incelemek, gönderen mi gönderilen mi, egemen özne mi, ezilen özne mi; yoksa diğer tarafla eşit konumda mı olduğuna bakmak gerekir" (Öztürk Kasar, 2009, 170). Öteki adamın, oğlu Joe'nun Morton'ın oğlu Larry'ye kum atmasını, oğlunun kum havuzunda oynama hakkına bağlaması, canı kum atmak isterse de atacağını açıkça söyleyerek oğluna bu konuda izin vermesi, "beğenmezse" Morton'ın çocuğunu da alıp oradan cehennem olup gidebileceğini söyleyerek dayattığı sözleşme, her iki tarafin da kazanacağı bir sözleşme değildir. Bu sözleşmeye göre Joe istediğini yapacak, istediği kadar kum atacak ve Morton buna razı gelip hiçbir şey söylemeyecek, ya da beğenmezse çocuğunu da alarak orayı terk edecektir. Sözleşmenin koşullarını öteki adam belirlemekte ve Morton'a başka bir seçenek bırakmamaktadır. Morton adamla mücadele etmek yerine sözleşmeye uyup çocuğunu da alarak çekip gitmektedir. Morton'ın bu sözleşmeye boyun eğmesi, belki de hayatındaki diğer 
bazı sözleşmelerin askıya alınmasına ve ya da tek taraflı olarak feshedilmesine de mal olabilecektir.

Bu örnekte öteki adam egemen özne, Morton ezilen öznedir ve hatta ne adamın karşısında ne de sözleşmede hükmü geçtiği için 'hükümsüz' öznedir. Öteki adamın muhatap bile almadığı kadın ise, doğrudan bu sözleşmenin içine dâhil gözükmese de dolaylı olarak olayın içindedir ve Morton'dan dolayı o da ezilen özne konumundadır.

Başka bir sözleşme örneği ise, eve gitmek istemeyen çocuğun yaptığı taşkınlıklara karşı olayın yarattığı tüm gerilimin ardından Morton'ın kadına “Bu çocuğa terbiyesini veremiyorsan, ben veririm" demesi ile ortaya çıkmaktadır. Bu sözleşmeye göre çocuğa terbiyesini ya karısı verecek ya da Morton verecektir. Morton, öteki adamla olan iletişiminin bir sonucu olarak üzerine yapışan ezilen özne sıfatından kurtulup, tekrar egemen özne konumunu kazanmak için kendisinin karısına büyüklük taşlamaktadır. Kadın çocuğu terbiye edemezse, Morton çocuğu başarıyla terbiye edecektir. Ancak karısı böyle bir sözleşmeyi kabul etmeyecek ve Morton'ın yüzünden düştüğü ezilen özne konumunun yine Morton'ın tarafindan pekiştirilip ikiye katlanmasına izin vermeyecek ve hatta Morton'a verdiği cevapla onu ezerek kendisi ona nazaran egemen özne konumuna geçebilecektir.

\section{Eyleyenlerin Kipsel Donanımlarının İncelenmesi}

"Eyleyenlerin kimliklerine kavuş(turul)ması için sahip olmaları gereken kiplikler söz konusudur: istemek, yapabilmek, bilmek ve zorunda olmak. Ĕ̆er eyleyenin kipsel donanımı istemek ile yönetiliyorsa, karşımızdaki özerk bir eyleyendir, zorunda olmak ile yönetiliyorsa bağımlı bir eyleyendir" (Öztürk Kasar, 2009, 168). Bir eyleyeni özerk eyleyen ya da bağımlı eyleyen olarak tanımlayabilmek için, başka bir eyleyen ile ilişkisine nazaran bir belirleme yapmak yerinde olacaktır. Başka bir deyişle, bir eyleyen başka bir eyleyenle ilişkisi bakımından bağımlı eyleyen konumunda iken, farklı bir eyleyen ile ilişkisi bakımından özerk eyleyen durumunda olabilir ve dünyadaki güç dengeleri de göz önüne alındığında, aslında bu aslında anlaşlabilir bir durumdur. Bağımlılık, özerklik, güçsüzlük ve güçlülük, göreceli kavramlardır ve bir bağlamda özerk olan kişi, diğer bir bağlamda bağımlı konumunda olabilir.

$\mathrm{Bu}$ anlamda, Morton öteki adam ile olan ilişkisi bakımından bağımlı bir eyleyendir, kendi istediğini değil, öteki adamın istediğini, başka bir deyişle, zorunda olduğunu yapmaktadır. Öteki adam, Morton ile ilişkisi bakımından özerk eyleyendir, ona istediğini yaptırabilmektedir. Öte yandan aynı Morton karısı ve çocuğu ile olan ilişkisi bakımından onları kendi başına aldığı parktan çıkma kararına uymak zorunda bırakması sırasında özerk eyleyendir. Ancak öykünün sonu, Morton'ın bu sıfatını parkın dışına çıkar çıkmaz kaybettiğini göstermektedir.

\section{Metnin çevirisine ilişkin notlar}

Çevrilecek bir yazınsal metnin özelliklerine uygun göstergebilimsel yöntemlerle çözümlenmesi, satır satır ve satır aralarıyla birlikte okunmasını ve böylece varış diline anlam evrenini tamamlayan tüm göstergeleriyle birlikte aktarılmasına katkıda bulunabilir. Örneğin bu çalışmada kullandığımız kesitleme yöntemi, öykünün dönüm noktalarını ve dönüsstürücü edimlerini vurgularken, yerdeşlikler, kipsel donanımlar ve sözleşmeler de karakterlerin arasındaki öyküyü belli bir sonuca yönlendiren açık ya da örtük ilişkileri ve bu ilişkilerdeki dengeleri açığa çıkarmaktadır. Çözümlemede kullanılan her bir yöntem dikkati bir okumayı zorunlu kıldığından, çevrilecek bir birimin atlanması ya da göstergelerin istem dışı dönüştürülmesi gibi olasılıkların göstergebilimsel çözümleme sayesinde aşılması umulabilir. 
Sunday in the Park, Türkçeye daha önce çevrilmediğinden, yapılmış çeviriler üzerinden bir değerlendirme yapmamız mümkün değildir. Ancak, yaptı̆̆ımız çözümlemeden yola çıkarak, öykü açısından özel önem taşıyabilecek göstergelerden örnek olarak alacağımız birkaçının dilimize olası aktarım seçeneklerinden söz edebiliriz.

\subsection{Başlı̆̆ı Çevirmek}

Öncelikle "bir yazınsal yapıtın başlığı onun oluşturduğu anlam evreninin giriș kapısıdır; bu kapının araladığı dünya ne kadar ilginç görünürse okuru o kadar içine çeker" (Öztürk Kasar, 2009, 166). Ancak incelediğimiz öykünün başlı̆̆ı, Sunday in the Park, sıradan bir başlık olup, çok özel bir merak uyandıracak nitelikte değildir. Çevirisi için yapılabilecek olası başlık tercihleri, Parkta Bir Pazar Günü ya da Parkta Pazar olarak düşünülebilir. Parkta Pazar başlığında yer alan her iki sözcüğün baş harfi de $p$ 'dir. $P$, sert sessiz ve patlayıcı bir sestir. Buna ek olarak, parkta sözcügündeki $k$ ve $t$ harfleri de $p$ ile aynı özellikte olup, sert, sessiz ve patlayıcıdır. Bu tür sesler, ses tellerini fazla titreştirmediği için sessiz olarak adlandırılır, ancak telaffuz edilirken ağızdan gelen havanın önce bir engele takılıp, sonrasında birdenbire o engeli aşması ile oluştuklarından, patlayıcı özellikleri vardır. İki sert sessiz patlayıcının başlıktaki sözcüklerin baş harflerinde ardı ardına kullanılmasının, başlığı daha net ve çarpıcı ya da daha ilginç bir hale getirebileceği düşünülebilir. Bununla birlikte, Pazar es sesli bir sözcüktür. Öykü başlığındaki Pazar, haftanın yedi gününden birini ifade etmektedir. Ancak sözcüğün, "satıcıların belirli günlerde mallarını satmak için sergiledikleri geçici yer, belli bir şeyin satıldığı yer ya da alışveriş"18 gibi anlamları da vardır. Öte yandan, Sunday sözcüğü birden fazla anlam ifade etmediğinden, Sunday in the Park başlığının anlamı açıktır. Oysa aktarımda Parkta Pazar başlığının kullanılması halinde, özgün metinde açı seçik bir biçimde dile getirilmiş anlam, belirsiz hale gelecek ve ortaya "bulanık anlam" (Öztürk Kasar, Tuna, 2015, 463) çıkacaktır. Bu nedenle, özgün metindeki kullanımı yansıtma kaygısı güdülüyorsa, Parkta Bir Pazar Günü başlı̆̆ tercih edilebilir.

\subsection{Dönüștürücü Edimi Çevirmek}

İlk kesitin ve dördüncü alt kesitin sonunu belirleyen, öteki adamın sarf ettiği "You and who else” ifadesi, öykünün seyrini değiştirecek bir dönüşüme yol açması nedeniyle özel önem taşımaktadır. Öteki adamla mantık ve terbiye çerçevesinde bir fikir alış verişinde bulunarak belli bir uzlaşmaya varabileceğini zanneden Morton, "I must ask you.." diye başladığ cümlesini bitirmesine öteki adam müsaade etmemekte "Oh yeah? [..] You and who else?" diye Morton'u susturarak onu bir tehdit olarak görmediğini ve hatta adam yerine bile koymadığını saldırgan ve küstah olduğu kadar, iğneleyici ve rencide edici bir şekilde ifade etmektedir.

"You and who else", birine meydan okumak, o kişinin yapacağını söylediği işi yapamayacağını iddia ederek o kişiyi küçümseyip hafife almak için kullanır. Özgün metinde 'Sorarım size..." diye başlayan ama adamın tamamlayamadığı ifadeye karşılık olarak "Sen kimsin ki bana soru soracaksın, sen tek başına bunu yapamazsın, yanında kimi getireceksin” anlamında çatışmacı bir üslup kullanılmıştır.

Bu meydan okumayı varış diline aktarırken "Sen ve başka kim(ler)" şeklinde bire bir karşıllı̆ı alındığında Türkçe ifade olarak kulağa alışıldık gelmemekte, özgün metindeki etki eksilmekte ve ayrıca anlam belirsiz hale gelerek ortaya "bulanık anlam" (Öztürk Kasar, Tuna, 2015, 463) çıkmaktadır. Oysa öykünün dönüştürücü edimi olan bu ifade, aynı zamanda öykünün sonunda kadın tarafindan tekrar edilerek öykünün kapanış tümcesi ve son noktası olarak

18 Türk Dil Kurumu Güncel Türkçe Sözlük, http://tdk.gov.tr/index.php?option=com_gts\&arama=gts\&guid= TDK.GTS. 56e7371cdef5d2.07760647 [14.03.2016].

Kurklareli Üniversitesi, Fen Edebiyat Fakïltesi, Türk Dilives Bölümü, Kayalı Kampüsü-Kırklareli/TÜRKIYYE e-posta: editor@rumelide.com
Adress

Kirklareli University, Faculty of Arts and Sciences, Department of

Turkish Language and Literature, Kayalı Campus-Kırklareli/TURKEY

e-mail: editor@rumelide.com 
ortaya yeniden çıkmaktadır. Bu nedenle bu ifade hem öteki adam tarafından söylendiği bağlama, hem de kadın tarafından tekrar edildiği bağlama uyum sağlayabilecek, "Sen mi? Kaç kişiyle birlikte?" ya da "Sen mi? Daha başka kiminle?" gibi bir ifadeyle ya da yine Morton'ın öteki adamı sorgulama konusunda tek başına kifayetsiz kalacağını, bu işe kalkışmak için birilerinden yardım alması gerektiğini vurgulayan çevirmenin karar vereceği bir başka aşağılayıcı ifade ile karşılanabilir. Ancak bu ifade hem metnin dönüştürücü edimi, hem de kapanış söylemi olduğu için açık ve net bir biçimde aktarılarak Morton'ın öteki adam ya da kendi karısı tarafından tek başına bir tehdit olarak algılanmadığı noktasında özgün metindeki etkiyi yansıtması özel önem taşımaktadır.

\section{3. Üslubu çevirmek}

Karakterlerin kullandıkları üslup konusunda yukarıda değinilen dönüştürücü edim üzerinden devam edecek olursak, öteki adamın Morton'a meydan okurken girizgâh olarak kullandığ1 “Oh yeah?” ve Morton'ın karısının aynı amaçla kullandığı "Indeed?” ünlemleri de anlamı pekiştirdiklerinden önem taşımaktadır. Bu ünlemler dilimize farklı şekillerde aktarılabilir: "Hadi ya?" / "Yok ya?" / "Hadi canım? / "Öyle mi" / "Hak(i)katen mi" / "Gerçekten mi?" / "Sahi mi?" "Cidden mi?" türünde, her biri konuşma diline özgü, ancak birbirinden farklı üslupları yansıtabilecek seçenekler çoğaltılabilir. Bu ya da benzeri olasılıklar arasından seçilecek ifadenin özgün metni daha iyi yansitılabilmesi için, karakterlerin öyküde sergiledikleri genel tarzla bağdaşık olmasına dikkat edilmesi yararlı olabilir.

Bu duruma başka bir örnek olarak, özgün metinde iki adamın birbirlerine "you" hitapları üzerinde durulabilir. Öncelikle, Türkçedeki ikinci tekil şahıs ve ikinci çoğul şahıs farkı İngilizcede bulunmamaktadır. Sen ya da siz hitaplarından birinin tercihi durumunda, genellikle resmî ve mesafeli bir iletişimde "siz" hitabının kullanıldığı, eğitimli, belli bir altyapısı ve aile terbiyesi olan kişilerin tanımadıkları ya da çok iyi tanımadıkları kişilere karşı "siz" hitabını kullanırken, daha eğitimsiz, farklı bir altyapıdan gelen kişilerin yabancılara da "sen" hitabını tercih ettikleri düşünülebilir. Öte yandan, Türk dili ve kültüründe kavgada kullanılan genel hitap tarzının "sen" olduğu göz önünde bulundurulabilir. Kavga, zaten nezaketin bir anlamda terk edildiği bir bağlamdır ve özellikle kavgayı çıkaran tarafın "siz" hitabı kullanması beklenmez. Bu anlamda varış dili ve kültüründeki genel olageliş dikkate alınarak, kibar Morton'ın öteki adama "siz" şeklinde ve öteki adamın da Morton'a 'sen' şeklinde hitap edeceği düşünülebilir.

Öykünün bütününde öteki adamın kaba saba görüntüsü ve beden dili konuşmasına da yansımaktadır. Morton'la yaptığı konuşmalar yüksek sesle ve tehditkâr olarak betimlenmekte, Morton'ın ise adamla kibarca ve nezaketle konuştuğu ifade edilmektedir. Ancak son aşamada, muhatabının uzlaşmaz tavrından emin olduktan sonra sesi tedirginlikten pürüzlü bir hal almaktadır. Konuşmalarda kullanılan sözcüklere ek olarak, bu sözcüklerin nasıl söylendiklerini açıklayan zarflar, söylemin vurgu ve tonlamalarını zihinde canlandırmamızı sağlamakta ve söylem üreticisinin niyetine ilişkin bir fikir vermektedir. Böylelikle yapılan göstergebilimsel çözümleme, bir söylemi varış diline aktarırken dilin sunduğu seçeneklerden bağlama en uygun olanının belirlenmesine yardımcı olmaktadır.

\subsection{Vurguyu çevirmek}

Öyküde kimi bölümler italik karakter kullanımı ile vurgulanmaktadır. Öncelikle, kadının iç sesine üç kez yer verilmiş ve her birinde de italik karakterler kullanılmıştır. Öykü her ne kadar zaten kadının bakış açısından anlatılsa da, bu kullanım ile kadının düşüncelerinin doğrudan aktarıldığı bölümler, öykünün normal anlatım akışından ayrı tutulmuştur. 
Bunun yanı sıra, öteki adam çocuğunun kum atma hakkını savunurken, kum havuzunun "halka açı" bir yer olduğunu italik harflerle vurgulamaktadır. Burada öteki adam kamusal alanda herkesin eşit haklara sahip olduğunu, kimsenin üstün olmadığını ve her tür statü farkını reddettiğini vurgulamakta ancak belki de çocuğun kum atma hakkı gibi bir temelsiz bir çıkış noktasından çatışmacı bir yaklaşımla hareket ederek bir tür aşağılık kompleksini de ortaya koymaktadır. Yazar, "halka açık" ifadesini farklı karakterde sunarak özellikle vurgulamıştır.

Son olarak, babası tarafından zorla parkın dışına sürüklenen Larry'nin eve gitmek istemediğini, yemek istemediğini, yemek sevmediğini söylerken kullandığı "want" / "istemek" ve "like" / "sevmek" sözcükleri italik ile yazılarak çocuğun yaptığı tonlamaya dikkat çekilmekte, çocuğun bu sözleri sürekli tekrar ettiğinden söz edilmektedir. Bu sözlerin vurgulanması, çocuğun parktan çıkmamak için ayak direme eylemini söylemle desteklediğini ortaya koyması açısından önemlidir. Öte yandan, bu tür bir vurgunun aktarılması sırasında varış dilinin tümce yapısına göre hareket etme durumu söz konusu olabilecektir. Özgün metinde vurgular "I don't want..." / "I don’t like... " şeklinde üç ayrı sözcükten oluşan ifadeler içinde yer almaktadır. Bu ifadeler, - Fransızcaya aktarılacak olsa, benzer tümce yapısından dolayı vurguya "Je ne veux pas..." / "Je n'aime pas..." şeklinde özgün metinle örtüşen bir konumda yer verilebilecekken, Türkçeye aktarıldığında vurguya ne şekilde yer verileceğinin belirlenmesi için bir karar alınması gerekecektir zira Türkçede bu ifadeler "istemiyorum" ve "sevmiyorum" şeklinde tek sözcük ile karşılık bulmaktadır. Bu durumda, bu ifadelerin bütünü italik karakterle vurgulanabileceği gibi, italik karakterler bir yana bırakılıp, vurgu Türkçeye özgü olarak heceleme ile "is-te-mi-yo-rum" / "sev-mi-yo-rum" şeklinde sağlanabilir ya da çevirmenin seçeceği başka bir yöntemle de karşılanabilir. Benzer bir örnek, öteki çocuk Larry'ye ikinci kez kum attığında, Larry'nin annesinin onu "Don't do that!" / "Yapma şunu!" sözleriyle uyarması noktasında da söz konusudur. Burada, "do" / "yapmak" sözcügüu italik harflerle yazılarak Larry'nin annesinin sert bir dille yaptığı uyarı metin üzerinde vurgulanmıștır. Bu vurgunun aktarımında da, Türkçeye uygun bir yol benimsenerek, yine ifadenin bütünü "yapma" şeklinde italik karakterlerle vurgulanabilir, yine heceleme tercih edilerek "yap-ma" șeklinde bir karșılık düşünülebilir ya da yine çevirmenin kararına bağlı olarak farklı bir vurgu yaratılabilir. Burada önemli olan yazarın yazılı metin üzerinde oluşturduğu vurguyu görmek, onu yok saymamak ve varış metninde hakkını vermektir.

Sonuç olarak metin bașka bir dile aktarılırken, farklı bir harf karakteri ile ya da başka bir şekilde vurgulanmış ifadelerin göz ardı edilmeyip mümkünse aynı şekilde, değilse varış diline uyumlu bir yöntemle yansıtılması önem tașımaktadır, zira "yalnızca belli bir sözcüğün vurgulanmasıyla birçok şey ima edilebilir" (Gula, 2007, 33). Bu nedenle de, yapılmış bir vurgunun yok sayılması, vurgunun anlattıklarını metinden eksiltecek ve "yetersiz anlam" (Öztürk Kasar, Tuna, 2015, 463) durumuna yol açacaktır.

\section{Sonuç}

Bu çalışmada, Bel Kaufman'ın Sunday in The Park adlı kısa öyküsü kesitlere ayrılmış ve her bir kesit ile alt kesit içeriğine uygun isimlerle etiketlenerek gerçeğe uygunluk durumları (olmak/görünmek), yerdeşlikler, sözleşmeler ve eyleyenlerin kipsel donanımları bağlamında çözümlenmiştir. Özgün metinde karmaşık olmayan bir dil kullanılmış olması, öykünün geçtiği zamanın günümüzden uzak olmaması, içeriğinin anlaşılması için özel bir altyapı gerekmemesi, öykünün zihinde kolayca canlandırılabilir olması gibi etkenler sayesinde çözümleme özel bir güçlük arz etmemiştir. Öte yandan, öykü ne kadar kısa ve yalın olsa da, bir metindeki anlam evreninin görünen ile söylenenin ötesinde olduğu çözümleme ile bir kez daha ortaya koyulmuştur.

Okurun alg1s1, bir metnin anlam evrenini yazarın kurgusundan öteye taşıyabilmektedir zira ne söylendiği kadar söylenenden ne anlaşıldığ 
taşımaktadır. Bunun ötesinde açık ya da örtük olarak söylenmediği halde anlaşılanlar da önemlidir. Öte yandan "her okur, bir yapıtı, kendi öznelliği ile, kendi hayat ansiklopedisinden ve kendi tutkularından yola çıkarak okur, ve böylece eserin gücül anlamlarından sadece bir bölümünü 'işleyebilir”' (Öztürk Kasar, 2006, 226). Bu çalışma kapsamında yapılan göstergebilimsel çözümleme de, metni alımlayan öznenin ürettiği anlam ve seçtiği çözümleme yöntemleri ile şekillenmiştir.

Çevirmen de her okur gibi alımlayan özne olarak metnin anlam üretimine katkıda bulunur, göstergebilim bu üretim sürecinde "çevirmenin okumalarını daha etkili ve amaca uygun, başka bir deyişe daha nitelikli kılabilir" (Öztürk Kasar, 2005, 47-48). Böylelikle çevirmen, oluşturacağı metni belli bir doğrultuda şekillendirir ve hatta yönlendirebilir. "Çalışmasının ilk aşamasında çevirmen, yazınsal yapıttaki anlamları kavramak için yola çıkan bir 'arayış öznesi' dir. [...] Bu birinci aşamayı başardıktan sonra, kavramıș olduğu bu anlam evrenini çeviri dilinde yeniden yaratmak için ikinci bir aşamaya girişir" (Öztürk Kasar, 2005, 48). Bu aşama, aslında göstergebilimsel çözümleme sırasında geçilen saptama sürecinden ardından gelen karar alma sürecidir. Bu aşamada çevirmen, birçok işin üstesinden gelir. Örneğin, bu çalışmamızda değindiğimiz gibi, varış dilindeki metnin başlığına karar verir, saptadığı dönüştürücü edimi varış dilinde aynı etki ile ifade etmenin yollarını arar, anlatıdaki genel üslup ile karakterlerin söylemlerindeki üslubu korumak için çaba gösterir, yazılı metin üzeride şeklen işlenmiş bir vurguyu yakalayarak aktarır. Varış dilindeki metnini, tüm bunları ve daha fazlasını yaparak oluşturur.

Bu çalışmada, Kaufman'ın kısa öyküsü üzerinden, göstergebilimsel çözümlemenin bir metnin incelikle okunmasına ve böylelikle metinde örtük ya da açı olarak yer alan göstergelerin saptanmasına sunacağı katkı gösterilmeye çalışılmıştır. Seçilen yöntemlerle yapılan çözümleme sonucunda, metnin olası çevirisinde dikkate alınabilecek kimi ayrıntılar saptanmış ve bunların üzerinde durulmuştur. Bu noktada, göstergebilimsel çözümlemenin, bir metnin okunması kadar, aktarılmasına da katkı sunacağı değerlendirilmektedir. Metni okumak için çözümleme yöntemlerinden yararlanan çevirmen metni adım adım sorgulayacak, bu yaklaşımla algısı göstergelere karşı seçicilik ve duyarlılık kazanacak, böylelikle dikkat ya da farkındalık eksikliğinden kaynaklanabilecek istem dışı anlam dönüşümlerinden sakınabilecektir. Böylelikle, göstergebilimin katkısıyla, kendisinden dikkatli ve nitelikli bir okur yaratan çevirmen, çevireceği metne özgüvenle yaklaşacak ve tüm bu kazanımların üretilecek varış metni üzerinde bir yansıması söz konusu olacaktır.

\section{Kaynakça}

Büyük Türkçe Sözlük. http://www.buyukturkcesozluk.net/arama.php?kelime=ko\%FEut+ oyun, [12.03.2016].

Genette, G. (1972). Figures III. Paris: Editions du Seuil.

Greimas, A.J., Courtés, J. (1982) Semiotics and Language: An Analytical Dictionary. çev. Larry Crist ve diğ. c.1. Bloomington: Indiana University Press.

Greimas, A.J., Courtés, (1979). J. Sémiotique: Dictionnaire Raisonné de la Théorie du Language. c.1. Paris: Hachette:

Gula, R. J. (2007) Nonsense: Red Herrings, Straw Men and Sacred Cows: How We Abuse Logic in our Everyday Language?. Mount Jackson: Axios.

Kaufman, B. (2012). "Introduction”. La Tigresse and Other Short Stories. New York: Open Road Integrated Media. 
Öztürk Kasar, S. (2006). "Contribution Sémiotique à la Quête du Sens en Traduction Littéraire”. Le Sens en Traduction. (ed. Marianne Lederer) Paris: Lettres Modernes Minard, 225-233.

Öztürk Kasar, S. (2009). "Pour une Sémiotique de la Traduction". La traduction et ses métiers, (ed. Colette Laplace, Marianne Lederer, Daniel Gile). Caen: Lettres Modernes Minard, 163-175

Öztürk Kasar, S. (2005). "Trois Notions-Clés Pour Une Approche Sémiotique de la Traduction: Discours, Sens et Signification dans Mon Nom est Rouge d'Orhan Pamuk", D’une Langue à l'autre, Essai sur la Traduction Littéraire, (ed. Magdalena Nowotna) Paris: Aux lieux d'être, 47-48.

Öztürk Kasar, S., Tuna D. (2015). "Yaşam, Yazın ve Yazın Çevirisi İçin Gösterge Okuma". Frankofoni Fransız Dili ve Edebiyat İnceleme ve Araştırmalar Ortak Kitabı. s.27. Ankara: Bizim Grup Basımevi, 457-482.

Nedir Ne Demek NND Sözlük, http://www.nedirnedemek.com/paralel-oyun-nedir-paraleloyun-ne-demek [12.03.2016].

Türk Dil Kurumu Güncel Türkçe Sözlük, http://tdk.gov.tr/index.php? Option=com _gts \&arama $=$ gts \& guid $=$ TDK.GTS.56e7371cdef $5 \mathrm{~d} 2.07760647$ [14.03.2016]. 